\title{
Gobelinite, the Co analogue of ktenasite from Cap Garonne, France, and Eisenzecher Zug, Germany
}

\author{
Stuart J. Mills ${ }^{1}$, Uwe Kolitsch ${ }^{2,3}$, Georges Favreau ${ }^{4}$, William D. Birch ${ }^{1}$, Valérie Galea-Clolus ${ }^{5}$, and \\ Johannes Markus Henrich ${ }^{6}$ \\ ${ }^{1}$ Geosciences, Museums Victoria, GPO Box 666, Melbourne, Victoria 3001, Australia \\ ${ }^{2}$ Mineralogisch-Petrographische Abt., Naturhistorisches Museum, Burgring 7, 1010 Vienna, Austria \\ ${ }^{3}$ Institut für Mineralogie und Kristallographie, Universität Wien, Althanstraße 14, 1090 Vienna, Austria \\ ${ }^{4}$ independent researcher: 421 Avenue Jean Monnet, 13090 Aix-en-Provence, France \\ 5 independent researcher: 10 rue Combe Noire, 83210 Solliès-Toucas, France \\ ${ }^{6}$ independent researcher: Im Großen Garten 3, 57548 Kirchen (Sieg), Germany
}

Correspondence: Stuart J. Mills (smills@museum.vic.gov.au)

Received: 13 April 2020 - Revised: 30 October 2020 - Accepted: 9 November 2020 - Published: 25 November 2020

\begin{abstract}
The new mineral gobelinite, ideally $\mathrm{CoCu}_{4}\left(\mathrm{SO}_{4}\right)_{2}(\mathrm{OH})_{6} \cdot 6 \mathrm{H}_{2} \mathrm{O}$, is a new member of the ktenasite group and the $\mathrm{Co}$ analogue of ktenasite, $\mathrm{ZnCu}_{4}\left(\mathrm{SO}_{4}\right)_{2}(\mathrm{OH})_{6} \cdot 6 \mathrm{H}_{2} \mathrm{O}$. It occurs at Cap Garonne (CG), Var, France (type locality), and Eisenzecher Zug (EZ), Siegerland, North Rhine-Westphalia, Germany (cotype locality). The mineral forms pale green, bluish green or greyish green, blocky to thin, lath-like crystals. They are transparent and non-fluorescent, with a vitreous, sometimes also pearly, lustre and a white streak having a pale-green cast. Mohs hardness is about 2.5. The crystals are brittle with an irregular fracture; no cleavage was observed. $D$ (meas.) is $2.95(2)$ and $D$ (calc.) is $2.907 \mathrm{~g} \mathrm{~cm}^{-3}$ (for empirical formula, CG). Common associates are brochantite and various other hydrated metal sulfates. Electron-microprobe analyses of the CG material yielded (wt. \%) $\mathrm{CuO} 42.45, \mathrm{CoO} 6.58, \mathrm{NiO} 3.37, \mathrm{ZnO} 3.14, \mathrm{SO}_{3} 22.12$, and $\mathrm{H}_{2} \mathrm{O} 22.62$ (calculated on structural grounds), and total $=100.30 \mathrm{wt} . \%$, giving the empirical formula (based on $20 \mathrm{O}$ atoms) $\left(\mathrm{Co}_{0.63} \mathrm{Ni}_{0.32} \mathrm{Zn}_{0.28} \mathrm{Cu}_{3.83}\right)_{\Sigma 5.06} \mathrm{~S}_{1.98} \mathrm{O}_{20} \mathrm{H}_{18.00}$. The simplified formula is $(\mathrm{Co}, \mathrm{Ni})(\mathrm{Cu}, \mathrm{Zn})_{4}\left(\mathrm{SO}_{4}\right)_{2}(\mathrm{OH})_{6} \cdot 6 \mathrm{H}_{2} \mathrm{O}$, and the endmember formula is $\mathrm{CoCu}_{4}\left(\mathrm{SO}_{4}\right)_{2}(\mathrm{OH})_{6} \cdot 6 \mathrm{H}_{2} \mathrm{O}$. Scanning electron microscopy-energy dispersive $\mathrm{X}$-ray spectroscopy (SEM-EDS) analyses of the (Zn-free) EZ material gave the simplified average formula $\left(\mathrm{Co}_{0.92} \mathrm{Ni}_{0.21} \mathrm{Mg}_{0.01} \mathrm{Cu}_{3.79}\right)_{\Sigma 4.93}\left(\mathrm{SO}_{4}\right)_{2.08}(\mathrm{OH})_{6} \cdot 6 \mathrm{H}_{2} \mathrm{O}$. Optically, gobelinite $(\mathrm{CG})$ is biaxial negative, with $\alpha=$ $1.576(2), \beta=1.617(2)$ and $\gamma=1.630(2) ; 2 V_{\text {meas }}=58(4)^{\circ}$ and $2 V_{\text {calc }}=57.5^{\circ}$. Dispersion is weak, $r>v$; orientation is $X=\beta, Y=\gamma$ and $Z \approx \alpha$, with strong pleochroism $X$ equaling colourless, $Y$ equaling green and $Z$ equaling pale green. The mineral is monoclinic, space group $P 2_{1} / c$, with $a=5.599(1), b=6.084(1)$, $c=23.676(5) \AA, \beta=95.22(3)^{\circ}$ and $V=803.2(3) \AA^{3}$ (at $100 \mathrm{~K}$; CG) and $a=5.611(1), b=6.103(1), c=$ $23.808(5) \AA, \beta=95.18(3)^{\circ}$ and $V=811.9(3) \AA^{3}$ (at $298 \mathrm{~K}$; EZ), respectively $(Z=2)$. The eight strongest measured powder X-ray diffraction lines ( $d$ in $\AA(I) h k l$ (CG material)) are 11.870 (100) 002, 5.924 (40) 004, 4.883 (10) 102, 4.825 (15) 013, 3.946 (15) 006, 2.956 (15) 008, 2.663 (20) 202 and 2.561 (15) 123. Single-crystal structure determinations gave $R_{1}=0.0310(\mathrm{CG})$ and $0.0280(\mathrm{EZ})$. The atomic arrangement is based on brucitelike sheets formed from edge-sharing, Jahn-Teller-distorted $\left(4+2\right.$ coordination) $\mathrm{CuO}_{6}$ octahedra. These sheets are decorated on both sides with $\mathrm{SO}_{4}$ tetrahedra and linked via hydrogen bonds to interstitial, fairly regular $\mathrm{Co}\left(\mathrm{H}_{2} \mathrm{O}\right)_{6}$ octahedra. The name alludes to the Old French word gobelin, equivalent to the German word kobold, from which the designation of the element cobalt was derived.
\end{abstract}




\section{Introduction}

The secondary hydrated $\mathrm{Zn}-\mathrm{Cu}$-sulfate ktenasite was first described from Lavrion, Greece, by Kokkoros (1950), who suggested the approximate formula $(\mathrm{Cu}, \mathrm{Zn})_{3} \mathrm{SO}_{4}(\mathrm{OH})_{2} \cdot 2 \mathrm{H}_{2} \mathrm{O}$. Nearly 30 years later, Raade (1977) and Olsen and Lewis (1979) provided new data on ktenasite from Norway and Colorado, USA, respectively, and the crystal structure (monoclinic, $P 2_{1} / c, a=5.589$ (1), $b=6.166(1), \quad c=23.751(7) \AA$ and $\left.\beta=95.55(1)^{\circ}\right)$ was finally published by Mellini and Merlino (1978). They showed that the mineral can be viewed as having the general formula $(M 1)_{2}(M 2)_{4}(M 3)_{4}\left(\mathrm{SO}_{4}\right)_{4}(\mathrm{OH})_{12} \cdot 12 \mathrm{H}_{2} \mathrm{O}$, where $M 1=\mathrm{Zn}$, or another minor divalent cation with near regular octahedral coordination geometry, and with $M 2$ and $M 3$ being sites with more or less Jahn-Teller-distorted octahedral coordination geometries, which are occupied by a mixture of $\mathrm{Cu}, \mathrm{Zn}$ or other cations. Mellini et al. (1981) provided details on the crystal chemistry of ktenasite and demonstrated that samples have appreciably variable $\mathrm{Zn}: \mathrm{Cu}$ ratios but noted that compositions with $\mathrm{Cu}: \mathrm{Zn}$ ratios near $1: 1$ are common. They proposed the general formula $\mathrm{Zn}\left(\mathrm{Cu}_{x} \mathrm{Zn}_{4-x}\right)\left(\mathrm{SO}_{4}\right)_{2}(\mathrm{OH})_{6} \cdot 6 \mathrm{H}_{2} \mathrm{O}$. Recently, after the approval of the $\mathrm{Mg}$ analogue of ktenasite with the name fehrite, $\mathrm{MgCu}_{4}\left(\mathrm{SO}_{4}\right)_{2}(\mathrm{OH})_{6} \cdot 6 \mathrm{H}_{2} \mathrm{O}$ (IMA2018125a; Schlüter et al., 2020), the ideal formula of ktenasite was modified in an executive decision taken by the IMA Commission on New Minerals, Nomenclature and Classification $(\mathrm{CNMNC})$ from $(\mathrm{Cu}, \mathrm{Zn})_{5}\left(\mathrm{SO}_{4}\right)_{2}(\mathrm{OH})_{6} \cdot 6 \mathrm{H}_{2} \mathrm{O}$ to $\mathrm{ZnCu}_{4}\left(\mathrm{SO}_{4}\right)_{2}(\mathrm{OH})_{6} \cdot 6 \mathrm{H}_{2} \mathrm{O}$ (Miyawaki et al., 2019).

Studies of ktenasites from many worldwide localities over the last two decades by the authors and colleagues in Austria and Australia have shown that the crystal chemistry of the mineral is quite variable and that some ktenasite samples actually represent new mineral species, in which $\mathrm{Zn}$ may be partially or fully replaced by $\mathrm{Mg}, \mathrm{Co}, \mathrm{Ni}$ and $\mathrm{Cd}$ (nomenclature proposal in preparation). Originally independent studies of the Co analogue of ktenasite from a French locality (Cap Garonne) and a German locality (Eisenzecher Zug mine), led by the first and second author, respectively, were combined to propose a new mineral species, with the name gobelinite, to the IMA-CNMNC. Both the mineral and name were approved in late 2018 (IMA2018-167). The name, pronounced (/grb(ə)lã: art/), is in reference to kobold (German), meaning "goblin", a superstitious term once used for the ore of cobalt by medieval miners. The etymology of both the element cobalt and cobaltite comes from the German word kobold (first used in the 16th century; Pfeifer, 2004), which itself originates from the Old French gobelin, used around 1195 in Ambroise of Normandy's Guerre sainte, and Medieval Latin gobelinus, used before 1141. Medieval miners in both Germany and France, as well as most of Europe, believed goblins to be expert miners and metalworkers who could be heard constantly drilling, hammering and shovelling. Legends suggest that goblins were evil creatures who poisoned ores in the mines, removed silver from ore and made it useless (kobold ore), and also made miners sick (Ashliman, 2006). The Cap Garonne ores contain $\mathrm{Pb}$ and $\mathrm{As}$, which form part of this folklore. The Eisenzecher Zug mine is poor in $\mathrm{Pb}$ and $\mathrm{As}$ but locally rich in Co ores. In order to avoid confusion with cobaltite and because the Cap Garonne locality is in France, we prefer to honour the Old French roots of the word gobelin.

Type material is preserved in the mineralogical collections of Geosciences, Museums Victoria, GP.O. Box 666, Melbourne, Victoria 3001, Australia, registration number M54565 (Cap Garonne), and the Naturhistorisches Museum, Burgring 7, 1010 Vienna, Austria, registration number O 1045 (Eisenzecher Zug).

\section{Occurrence}

Gobelinite was found by Valérie Galea-Clolus on specimens from the famous Cap Garonne mine (Favreau and GaleaClolus, 2014), Var, Provence-Alpes-Côte d'Azur, France (type locality; $43^{\circ} 4^{\prime} 53^{\prime \prime} \mathrm{N}, 6^{\circ} 1^{\prime} 55^{\prime \prime} \mathrm{E}$ ), the type locality for 14 other minerals. More specifically, the type specimen of gobelinite was collected at pillar 78b in the north mine. Gobelinite is restricted to an area of the mine, called "fond de mine", where most of the new species were found at Cap Garonne. Gobelinite has also been found in pillars 78, 79 and 80.

Gobelinite was also found in 1997 on specimens from the Schlänger und Eichert vein of the Eisenzecher Zug mine (cotype locality; 50 $49^{\prime} 9^{\prime \prime} \mathrm{N}, 7^{\circ} 59^{\prime} 14^{\prime \prime} \mathrm{E}$ ), Eiserfeld, Siegerland, North Rhine-Westphalia, Germany, by Johannes Markus Henrich. The Eisenzecher Zug mine, which consolidated several older mines, worked on $\mathrm{Fe}-(\mathrm{Cu}-\mathrm{Co})$ ores and was the most important mine in the Siegerland mining district (Henrich, 1998). The occurrence of gobelinite was restricted to a small, fissure-like area in an adit. In subsequent years, no additional material could be found.

\section{Appearance and physical properties}

At Cap Garonne, gobelinite occurs mostly as vitreous crystals, sometimes with a pearly lustre. Their colour is usually pale green and rarely bluish green. No colour zoning was observed in individual crystals. The crystal size is commonly 0.1 to $0.2 \mathrm{~mm}$ and rarely up to $0.5 \mathrm{~mm}$ in length. The crystals are blocky to thin and lath-like, with sharp rectangular outlines (Fig. 1). Crystals are elongated on [010] and flattened on $\{001\}$. Forms observed are $\{001\},\{031\}$ and $\{201\}$ (Fig. 2). The crystals often form in the spaces between quartz grains, or between quartz pebbles and conglomerate. The crystals may be scattered or in groups forming fans or rosettes, sometimes densely covering the conglomerate matrix; they are mostly flat lying and more rarely free standing. The principal associated minerals are brochantite, cerussite and gordaite-group minerals ("guarinoite", thérèse- 


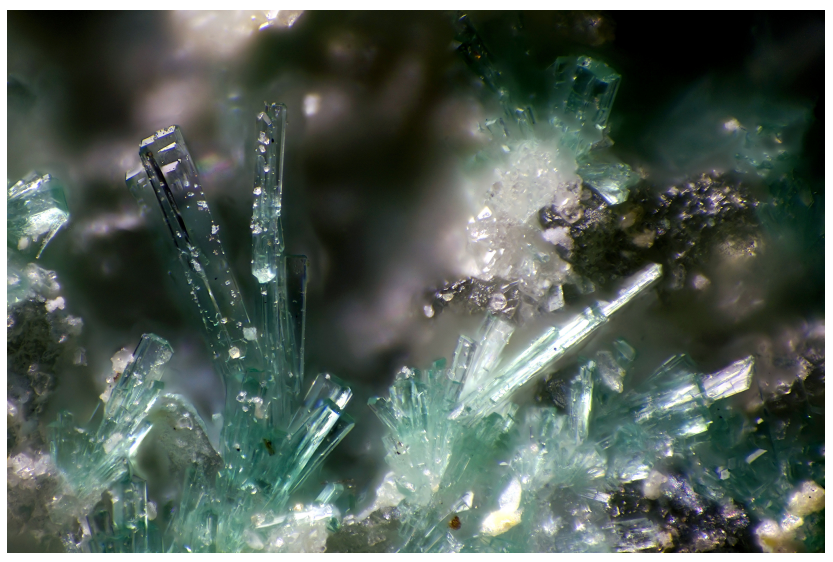

Figure 1. Lath-shaped pale-greenish crystals of gobelinite from pillar 78b, Cap Garonne, France. Field of view is $1 \mathrm{~mm}$. Photo: Pierre Clolus. Collection: Valérie Galea-Clolus.

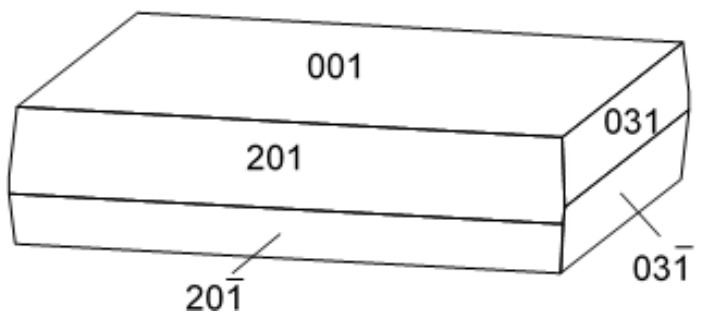

Figure 2. Clinographic projection of a gobelinite crystal from Cap Garonne, France. Drawn with FACES (Favreau, 2005).

magnanite and pale-green gordaite; Mills et al., 2019). The accessory associated species are serpierite, botallackite and an unknown copper sulfate currently under study. Sarp et al. (1990) also mentioned antlerite and anglesite at pillar 80 in association with what they called "cobalt-nickelktenasite" and for which they gave the empirical formula $\left(\mathrm{Cu}_{3.53} \mathrm{Co}_{0.80} \mathrm{Ni}_{0.61} \mathrm{Zn}_{0.23}\right)_{\Sigma 5.17}\left(\mathrm{SO}_{4}\right)_{1.98}(\mathrm{OH})_{6.38} \cdot 5.7 \mathrm{H}_{2} \mathrm{O}$. Gobelinite is likely to have formed from the weathering of cobaltite-gersdorffite and nearby tennantite under acidic conditions.

At Eisenzecher Zug, gobelinite occurs as greyish green to pale greyish green, indistinct to lath-shaped, prismatic or acicular, subparallel, translucent crystals. The crystal length size ranges between 0.2 and $0.5 \mathrm{~mm}$. On two other, noncotype specimens from the same material, pale greyish green, prismatic to acicular crystals form coral-like aggregates or sprays (flat lying, rarely free standing). The main associated mineral is brochantite (dark green globular aggregates, slightly Co-bearing). In the immediate vicinity of gobelinite, the following subordinate minerals were observed apart from brochantite: devilline (determined by powder X-ray diffraction), malachite, asbolane, spherocobaltite, langite, "sericite" and some unidentified phases. Gobelinite originated due to weathering, under acidic conditions, of a primary $\mathrm{Cu}-\mathrm{Co}$ ore paragenesis composed of chalcocite, djurleite, carrollite (as aggregates, up to $3 \mathrm{~cm}$ in size, of interlocking single crystals); locally hematite; and, less commonly, pyrite, bornite, alloclasite and chalcopyrite. Gobelinite is directly grown on either quartz, siderite, carrollite or the slate country rock. Fewer than 10 gobelinite-bearing specimens were found.

Based on the two occurrences, gobelinite can be described as pale green, bluish green or greyish green with a white streak which has a pale-green cast. Crystals are vitreous, transparent - sometimes with a pearly lustre - and are nonfluorescent. Hardness is about 2.5 on the Mohs scale. Crystals are brittle with an irregular fracture; no cleavage was observed. The density measured by the sink-float method in Clerici solution is $2.95(2) \mathrm{g} \mathrm{cm}^{-3}$ (CG), while the calculated density based on the empirical formula and unit cell is $2.907 \mathrm{~g} \mathrm{~cm}^{-3}$ (CG). The X-ray density values from the single-crystal refinements (see Sect. 4) are 2.958 and $2.926 \mathrm{~g} \mathrm{~cm}^{-3}$ for CG and EZ material, respectively.

Optical measurements were undertaken on the Cap Garonne material. Gobelinite is biaxial (-), with the following indices of refraction: $\alpha=1.576(2), \beta=1.617(2)$ and $\gamma=1.630(2)$, measured in white light. $2 V_{\text {meas }}$ is $58(4)^{\circ}$ by direct measurement on a spindle stage and $2 V_{\text {calc }}$ is $57.5^{\circ}$. Dispersion: $r>v$, weak; and orientation: $X=\beta, Y=\gamma$ and $Z \approx \alpha$, with $X$ equaling colourless, $Y$ equaling green and $Z$ equaling pale green. The Gladstone-Dale compatibility (Mandarino, 2007) is 0.011, superior, for the data from Cap Garonne.

\section{Chemical data}

Quantitative wavelength-dispersive electron-microprobe analyses (10 points) of gobelinite from Cap Garonne were carried out using a JEOL Superprobe electron microprobe at the University of Melbourne. Operating conditions were $20 \mathrm{kV}, 5 \mathrm{nA}$ and a $20 \mu \mathrm{m}$ defocused beam diameter. The ZAF correction method was used. No other elements apart from $\mathrm{Co}, \mathrm{Ni}, \mathrm{Zn}, \mathrm{Cu}, \mathrm{Al}, \mathrm{S}$ and $\mathrm{O}$ were detected by energydispersive spectroscopy. Insufficient material is available for direct determination of water. The $\mathrm{H}_{2} \mathrm{O}$ content was therefore calculated on the basis of $6 \mathrm{H}_{2} \mathrm{O}+6(\mathrm{OH})$, in accordance with the results of the crystal-structure refinement. Analytical data are given in Table 1. The empirical formula (based on 20 $\mathrm{O}$ atoms $)$ is $\left(\mathrm{Co}_{0.63} \mathrm{Ni}_{0.32} \mathrm{Zn}_{0.28} \mathrm{Cu}_{3.83}\right)_{\Sigma 5.06} \mathrm{~S}_{1.98} \mathrm{O}_{20} \mathrm{H}_{18.00}$ (which includes rounding errors). The simplified formula is $(\mathrm{Co}, \mathrm{Ni})(\mathrm{Cu}, \mathrm{Zn})_{4}\left(\mathrm{SO}_{4}\right)_{2}(\mathrm{OH})_{6} \cdot 6 \mathrm{H}_{2} \mathrm{O}$, and the endmember formula is $\mathrm{CoCu}_{4}\left(\mathrm{SO}_{4}\right)_{2}(\mathrm{OH})_{6} \cdot 6 \mathrm{H}_{2} \mathrm{O}$, which requires $\mathrm{CuO} 44.48, \mathrm{CoO} 10.47, \mathrm{SO}_{3} 22.38$ and $\mathrm{H}_{2} \mathrm{O}$ 22.67, total 100.00 wt. \%.

Gobelinite from the Eisenzecher Zug mine was characterised by multiple SEM-EDS spot analyses of several carbon-coated grains (JEOL JSM-6610LV at the Natural History Museum, Vienna, Austria, Bruker e-FlashHR+ detector with resolution $127 \mathrm{eV}$, Bruker Esprit 2.0 software, $15 \mathrm{kV}$, spot size $1 \mu \mathrm{m}, 60 \mathrm{~s}$ measuring time and PB-ZAF 
Table 1. Analytical results $(n=9)$ for gobelinite from Cap Garonne.

\begin{tabular}{lrrrl}
\hline Const. & wt. \% & Range & SD & standard \\
\hline $\mathrm{CuO}$ & 42.45 & $38.77-45.45$ & 1.84 & $\mathrm{Cu}$ metal $(K \alpha)$ \\
$\mathrm{CoO}$ & 6.58 & $5.75-7.38$ & 0.57 & Co metal $(K \alpha)$ \\
$\mathrm{ZnO}$ & 3.14 & $2.18-5.12$ & 0.96 & $\mathrm{Zn}$ metal $(K \alpha)$ \\
$\mathrm{NiO}$ & 3.37 & $3.00-3.57$ & 0.19 & $\mathrm{NiFe}(K \alpha)$ \\
$\mathrm{Al}_{2} \mathrm{O}_{3}$ & 0.02 & $0-0.04$ & 0.01 & $\mathrm{Al}_{2} \mathrm{O}_{3}(K \alpha)$ \\
$\mathrm{SO}_{3}$ & 22.12 & $21.50-22.73$ & 0.40 & $\mathrm{SrSO}_{4}(K \alpha)$ \\
$\mathrm{H}_{2} \mathrm{O}_{\text {calc }}$ & 22.62 & & & \\
\hline Total & 100.30 & & & \\
\hline
\end{tabular}

correction). These grains were removed from the same crystal aggregate that furnished the fragment used for the crystal-structure determination. No beam-induced sample damage was observed. The accuracy of the obtained at. \% values is estimated to be better than $5 \%$ (except the $\mathrm{O}$ value). All analyses show major $\mathrm{Cu}$, minor $\mathrm{Co}$ and $\mathrm{S}$, very minor $\mathrm{Ni}$, and, in some cases, traces of $\mathrm{Mg}$ and $\mathrm{Mn}$ but no $\mathrm{Zn}$ (unlike the CG material). Nine spot analyses, performed on several fragments, evidence only minor chemical variability and gave the following average empirical formula: $\left(\mathrm{Co}_{0.92} \mathrm{Ni}_{0.21} \mathrm{Mg}_{0.01} \mathrm{Cu}_{3.79}\right)_{\Sigma 4.93}\left(\mathrm{SO}_{4}\right)_{2.08}(\mathrm{OH})_{6} \cdot 6 \mathrm{H}_{2} \mathrm{O}$ (normalised on seven $M+\mathrm{S}$ atoms, assuming $6 \mathrm{H}_{2} \mathrm{O}+$ $6(\mathrm{OH})$ and excluding one outlier analysis with an anomalously high $\mathrm{S}: M$ ratio). Apart from minor substitutional differences, the two occurrences of gobelinite thus have very similar chemical compositions.

\section{Crystallography}

\subsection{Cap Garonne}

The single-crystal X-ray diffraction experiment was carried out on the microfocus macromolecular MX2 beamline at the Australian Synchrotron, part of the Australian Nuclear Science and Technology Organisation (ANSTO). A $10 \times$ $10 \times 2 \mu \mathrm{m}$ light-green fragment was selected. A full Ewald sphere of intensity data was collected at $100 \mathrm{~K}$ by a Dectris EigerX $16 \mathrm{M}$ detector and monochromatic radiation with a wavelength of $0.71073 \AA$. The dataset was processed using XDS (Kabsch, 2010), XPREP (Bruker, 2001) and SADABS (Bruker, 2001), leading to an $R_{\text {int }}$ of 0.0315 . The crystal structure was solved by direct methods using SHELXT 2014/5 (Sheldrick, 2015b). All atoms were located, and the obtained structure model confirmed the ktenasite model of Mellini and Merlino (1978). The structure was refined with SHELXL-2016/6 (Sheldrick, 2015a), with anisotropic treatment of all non- $\mathrm{H}$ atoms. The $U_{\text {iso }}$ values of the hydrogen atoms were constrained to $0.029 \AA^{2}$, and the $\mathrm{O}-\mathrm{H}$ bond lengths were restrained to $0.90(2) \AA$. For the final refinement step, the coordinate set for ktenasite (Mellini and Merlino,
Table 2. Powder X-ray diffraction data for gobelinite from Cap Garonne.

\begin{tabular}{lrrrr}
\hline$h k l$ & $d_{\text {obs }}(\AA)$ & $d_{\text {calc }}(\AA)$ & $I_{\text {obs }}$ & $I_{\text {calc }}$ \\
\hline $\mathbf{0 0 2}$ & $\mathbf{1 1 . 8 7 0}$ & $\mathbf{1 1 . 8 7 0}$ & $\mathbf{1 0 0}$ & $\mathbf{1 0 0}$ \\
$\mathbf{0 0 4}$ & $\mathbf{5 . 9 2 4}$ & $\mathbf{5 . 9 2 4}$ & $\mathbf{4 0}$ & $\mathbf{4 0}$ \\
102 & 4.883 & 4.883 & 10 & 10 \\
$\mathbf{0 1 3}$ & $\mathbf{4 . 8 2 5}$ & $\mathbf{4 . 8 2 4}$ & $\mathbf{1 5}$ & $\mathbf{1 5}$ \\
$\overline{1} 11$ & 4.101 & 4.101 & 10 & 9 \\
$\mathbf{0 0 6}$ & $\mathbf{3 . 9 4 6}$ & $\mathbf{3 . 9 4 6}$ & $\mathbf{1 5}$ & $\mathbf{1 3}$ \\
015 & 3.738 & 3.738 & 10 & 9 \\
$\overline{1} 06$ & 3.367 & 3.367 & 5 & 4 \\
$\mathbf{0 0 8}$ & $\mathbf{2 . 9 5 6}$ & $\mathbf{2 . 9 5 6}$ & $\mathbf{1 5}$ & $\mathbf{1 4}$ \\
200 & 2.786 & 2.786 & 10 & 9 \\
$\mathbf{2 0 2}$ & $\mathbf{2 . 6 6 3}$ & $\mathbf{2 . 6 6 5}$ & $\mathbf{2 0}$ & $\mathbf{1 7}$ \\
$\overline{1} 23$ & 2.561 & 2.561 & 15 & 13 \\
204 & 2.434 & 2.434 & 10 & 9 \\
$\overline{1} 25$ & 2.367 & 2.366 & 10 & 9 \\
125 & 2.280 & 2.279 & 5 & 6 \\
206 & 2.180 & 2.180 & 5 & 4 \\
$\overline{1} 27$ & 2.136 & 2.136 & 10 & 11 \\
$\overline{1} 29$ & 1.908 & 1.908 & 8 & 6 \\
$\overline{2} 1.11$ & 1.702 & 1.702 & 5 & 4 \\
\hline & & & &
\end{tabular}

The strongest lines are marked in bold. Indexing is based on the crystal-structure models.

1978) was adopted, and site populations were fixed based on EMPA; the calculations resulted in $R_{1}=0.0310$ for 2386 $F_{\mathrm{O}}>4 \sigma\left(F_{\mathrm{o}}\right)$ and $R_{1}=0.0312$ for all 2419 data. Refined unit-cell parameters are $a=5.5990(11), b=6.0840(12)$, $c=23.676(5) \AA, \beta=95.22(3)^{\circ}, V=803.2(3) \AA^{3}$ and $Z=$ 2 .

Powder X-ray diffraction data of the CG material were recorded using an Agilent SuperNova dual-source diffractometer with an Atlas charge-coupled device (CCD) detector. Data were measured at ambient temperature using Mo $K \alpha$ radiation. Data are given in Table 2. Refined unitcell parameters, which are slightly larger than the singlecrystal ones due to the higher measurement temperature, are $a=5.6098(12), b=6.0981(7), c=23.800(5) \AA, \beta=$ 95.20(6) $)^{\circ}, V=810.8(9) \AA^{3}$ and $Z=2$.

\subsection{Eisenzecher Zug}

A crystal fragment of gobelinite, optically homogeneous and with the dimensions $0.05 \times 0.05 \times 0.13 \mu \mathrm{m}$, was used. A full sphere of X-ray diffraction intensity data up to $2 \theta=60.08^{\circ}$ was collected at room temperature at the Institut für Mineralogie und Kristallographie, Universität Wien, with a Nonius KappaCCD single-crystal X-ray diffractometer equipped with a $\mathrm{CCD}$ area detector, and using monochromatised $\mathrm{Mo} K \alpha$ radiation. Standard processing, with multi-scan absorption correction (Otwinowski et al., 2003 ), yielded $R_{\text {int }}=0.0259$ and gave the following crystal data: $a=5.611(1), b=6.103(1), c=23.808(5) \AA, \beta=$ 
95.18(3) ${ }^{\circ}, V=811.9(3) \AA^{3}$ and $Z=2$. Using the ktenasite model of Mellini and Merlino (1978), the structure was refined with SHELXL-97 (Sheldrick, 2008), with anisotropic treatment of all non- $\mathrm{H}$ atoms. All $\mathrm{O}-\mathrm{H}$ bond lengths were restrained to $0.85(4) \AA$ and $\mathrm{O}-\mathrm{H}$ distances to $1.50(4) \AA$, in order to obtain a reasonably correct geometry of the $\mathrm{H}_{2} \mathrm{O}$ ligands. The refinement converged at $R_{1}=0.0289$ for 1998 $F_{\mathrm{o}}>4 \sigma\left(F_{\mathrm{o}}\right)$ and $R_{1}=0.0400$ for all 2352 data.

The final atomic positions and equivalent/isotropic displacement parameters for both CG and EZ crystals are given in Table 3. Tabulated anisotropic displacement parameters are provided in Table S1 in the Supplement. Selected bond lengths are given in Table 4.

\section{Crystal structure}

The structure of gobelinite is isostructural with that published by Mellini and Merlino (1978) for ktenasite (see also Mellini et al., 1981, for details on the crystal chemistry). The crystal structure of gobelinite is comprised of a brucite-like sheet formed from edge-sharing, Jahn-Teller-distorted (4+2 coordination) $\mathrm{CuO}_{6}$ octahedra centred by the $\mathrm{Cu} 1$ and $\mathrm{Cu} 2$ sites. The sheets are decorated on both sides with $\mathrm{SO}_{4}$ tetrahedra and linked via hydrogen bonds to interstitial, fairly regular $\mathrm{Co}\left(\mathrm{H}_{2} \mathrm{O}\right)_{6}$ octahedra (range of $\mathrm{Co}-\mathrm{O}$ bond lengths: 2.061-2.092 for sample CG and 2.072-2.098 for sample EZ; Table 4). The $\langle\mathrm{Co}-\mathrm{O}\rangle$ bond lengths in gobelinite, $2.072 \AA$ (Cap Garonne) and $2.082 \AA$ (Eisenzecher Zug), are close to the grand mean value of $2.1115(621) \AA$ for $\mathrm{Co}(\mathrm{II}) \mathrm{O}_{6}$ polyhedra in inorganic compounds (Wildner, 1992), considering the partial substitutions of $\mathrm{Co}$ by $\mathrm{Ni}$ (and $\mathrm{Zn}$ at $\mathrm{CG}$ ). These two different substitutions would both make the polyhedra slightly smaller because the ionic radii for octahedral coordination of both $\mathrm{Zn}^{2+}(0.740 \AA)$ and $\mathrm{Ni}^{2+}(0.690 \AA)$ are slightly smaller than that of $\mathrm{Co}^{2+}(0.745 \AA$; values from Shannon, 1976). The corresponding $\langle\mathrm{Zn}-\mathrm{O}\rangle$ values in ktenasite are larger (2.089-2.097 $\AA$ for samples from various localities and with different $\mathrm{Cu}: \mathrm{Zn}$ ratios and additional minor substituting elements ( $\mathrm{Mg}, \mathrm{Ni}$ and $\mathrm{Cd}$ ); unpublished data of Kolitsch, Giester, Leverett, Sciberras, Williams and Hibbs). The $\langle\mathrm{Cu} 1-\mathrm{O}\rangle$ bond lengths in gobelinite (Table 4 ) are similar to those in ktenasite, while the $\langle\mathrm{Cu} 2-\mathrm{O}\rangle$ bond lengths are slightly shorter in gobelinite (2.101 and 2.105 $\AA$ for CG and EZ crystals, respectively) than in ktenasite (2.117-2.122 $\mathrm{A}$ ). However, both $\mathrm{Cu}_{1} \mathrm{O}_{6}$ and $\mathrm{Cu}_{2} \mathrm{O}_{6}$ octahedra are more (JahnTeller) distorted in gobelinite than in ktenasite. This is explained by the incorporation of minor $\mathrm{Zn}$ in both polyhedra in ktenasite. The $\langle\mathrm{S}-\mathrm{O}\rangle$ bond lengths obtained from both gobelinite refinements are comparable $(1.478 \AA$ for $\mathrm{CG}$ and $1.474 \AA$ for EZ) and close to the expected value for sulfate minerals (1.473 $\AA$; Hawthorne et al., 2000).
Table 3. Atom coordinates and equivalent/isotropic displacement parameters $\left(\AA^{2}\right)$ for gobelinite from Cap Garonne (every first line) and Eisenzecher Zug (every second line).

\begin{tabular}{|c|c|c|c|c|}
\hline Site & $x$ & $y$ & $z$ & $U_{\text {eq }} / U_{\text {iso }}$ \\
\hline $\mathrm{Co}^{\mathrm{a}}$ & 0 & 0 & 0 & $0.01366(11)$ \\
\hline $\mathrm{Co}^{\mathrm{b}}$ & 0 & 0 & 0 & $0.01809(13)$ \\
\hline \multirow[t]{2}{*}{$\mathrm{Cu} 1^{\mathrm{c}}$} & $-0.00771(4)$ & $0.10363(5)$ & $0.248931(9)$ & $0.01017(10)$ \\
\hline & $-0.00780(5)$ & $0.10031(5)$ & $0.248955(13)$ & $0.01593(9)$ \\
\hline \multirow[t]{2}{*}{$\mathrm{Cu} 2^{\mathrm{c}}$} & $0.49873(3)$ & $-0.14739(5)$ & $0.247275(9)$ & $0.01024(10)$ \\
\hline & $0.49902(5)$ & $-0.15036(5)$ & $0.247407(12)$ & $0.01500(9)$ \\
\hline \multirow[t]{2}{*}{$S$} & $0.36596(8)$ & $0.05850(8)$ & $0.374342(18)$ & $0.01399(12)$ \\
\hline & $0.36466(11)$ & $0.05778(10)$ & $0.37396(2)$ & $0.01770(14)$ \\
\hline \multirow[t]{2}{*}{$\mathrm{O} 1$} & $0.3392(3)$ & $0.0984(2)$ & $0.31238(6)$ & $0.0146(3)$ \\
\hline & $0.3383(3)$ & $0.0963(3)$ & $0.31212(7)$ & $0.0182(4)$ \\
\hline \multirow[t]{2}{*}{$\mathrm{O} 2$} & $0.6043(3)$ & $0.1076(2)$ & $0.20880(6)$ & $0.0130(3)$ \\
\hline & $0.6051(3)$ & $0.1045(3)$ & $0.20936(8)$ & $0.0164(4)$ \\
\hline \multirow[t]{2}{*}{$\mathrm{O} 3$} & $0.8426(2)$ & $0.3575(2)$ & $0.28851(6)$ & $0.0126(3)$ \\
\hline & $0.8418(3)$ & $0.3545(3)$ & $0.28838(8)$ & $0.0159(3)$ \\
\hline \multirow[t]{2}{*}{$\mathrm{O} 4$} & $0.1620(2)$ & $0.3508(2)$ & $0.21525(6)$ & $0.0114(3)$ \\
\hline & $0.1613(3)$ & $0.3469(3)$ & $0.21526(8)$ & $0.0151(3)$ \\
\hline \multirow[t]{2}{*}{$\mathrm{O} 5$} & $0.1310(3)$ & $-0.0072(3)$ & $0.39257(7)$ & $0.0203(3)$ \\
\hline & $0.1314(4)$ & $-0.0060(3)$ & $0.39222(8)$ & $0.0289(4)$ \\
\hline \multirow[t]{2}{*}{ O6 } & $0.4483(3)$ & $0.2639(3)$ & $0.40340(7)$ & $0.0249(3)$ \\
\hline & $0.4473(4)$ & $0.2624(3)$ & $0.40231(9)$ & $0.0321(5)$ \\
\hline \multirow[t]{2}{*}{$\mathrm{O} 7$} & $0.5444(3)$ & $-0.1169(3)$ & $0.38672(6)$ & $0.0197(3)$ \\
\hline & $0.5423(4)$ & $-0.1161(3)$ & $0.38642(8)$ & $0.0281(5)$ \\
\hline \multirow[t]{2}{*}{$\mathrm{O} 8$} & $0.9182(3)$ & $0.0595(3)$ & $0.08310(6)$ & $0.0190(3)$ \\
\hline & $0.9149(4)$ & $0.0606(4)$ & $0.08260(8)$ & $0.0278(4)$ \\
\hline \multirow[t]{2}{*}{ O9 } & $0.3262(3)$ & $0.1542(3)$ & $0.01773(6)$ & $0.0191(3)$ \\
\hline & $0.3248(4)$ & $0.1595(3)$ & $0.01780(9)$ & $0.0266(4)$ \\
\hline \multirow[t]{2}{*}{$\mathrm{O} 10$} & $0.1382(3)$ & $-0.2989(2)$ & $0.02800(6)$ & $0.0191(3)$ \\
\hline & $0.1401(4)$ & $-0.2981(3)$ & $0.02861(9)$ & $0.0267(4)$ \\
\hline \multirow[t]{2}{*}{$\mathrm{H} 2$} & $0.545(5)$ & $0.133(6)$ & $0.1728(9)$ & 0.029 \\
\hline & $0.562(6)$ & $0.121(5)$ & $0.1802(11)$ & $0.025(10)$ \\
\hline \multirow[t]{2}{*}{ H3 } & $0.866(6)$ & $0.358(6)$ & $0.3260(8)$ & 0.029 \\
\hline & $0.863(7)$ & $0.359(6)$ & $0.3206(12)$ & $0.043(11)$ \\
\hline \multirow[t]{2}{*}{$\mathrm{H} 4$} & $0.152(6)$ & $0.365(6)$ & $0.1815(15)$ & 0.029 \\
\hline & $0.153(7)$ & $0.361(6)$ & $0.1842(12)$ & $0.038(11)$ \\
\hline \multirow[t]{2}{*}{ H81 } & $0.882(6)$ & $0.198(3)$ & $0.0892(14)$ & 0.029 \\
\hline & $0.895(6)$ & $0.190(4)$ & $0.0889(14)$ & $0.035(10)$ \\
\hline \multirow[t]{2}{*}{ H82 } & $0.793(5)$ & $-0.023(5)$ & $0.0912(14)$ & 0.029 \\
\hline & $0.800(6)$ & $-0.020(5)$ & $0.0898(16)$ & $0.050(12)$ \\
\hline \multirow[t]{2}{*}{ H91 } & $0.425(5)$ & $0.215(5)$ & $-0.0055(11)$ & 0.029 \\
\hline & $0.421(8)$ & $0.184(8)$ & $-0.0070(15)$ & $0.093(18)$ \\
\hline \multirow[t]{2}{*}{ H92 } & $0.378(5)$ & $0.232(5)$ & $0.0483(10)$ & 0.029 \\
\hline & $0.361(6)$ & $0.231(6)$ & $0.0461(13)$ & $0.047(11)$ \\
\hline \multirow[t]{2}{*}{ H101 } & $0.272(4)$ & $-0.282(5)$ & $0.0523(11)$ & 0.029 \\
\hline & $0.259(5)$ & $-0.284(6)$ & $0.0478(14)$ & $0.039(10)$ \\
\hline \multirow[t]{2}{*}{$\mathrm{H} 102$} & $0.042(5)$ & $-0.368(5)$ & $0.0487(12)$ & 0.029 \\
\hline & $0.032(6)$ & $-0.372(7)$ & $0.0424(18)$ & $0.073(15)$ \\
\hline
\end{tabular}

a Occupancy fixed: $\mathrm{Co}_{0.62} \mathrm{Ni}_{0.32} \mathrm{Zn}_{0.06} \cdot{ }^{\mathrm{b}}$ Occupancy fixed: $\mathrm{Co}_{0.92} \mathrm{Ni}_{0.08}$.

c Occupancy fixed: $\mathrm{Cu}_{0.95} \mathrm{Zn}_{0.05}$. 
Table 4. Selected bond distances $(\AA)$ for the coordination polyhedra in gobelinite.

\begin{tabular}{rrrrrr}
\hline & $\mathrm{CG}$ & $\mathrm{EZ}$ & & $\mathrm{CG}$ & $\mathrm{EZ}$ \\
\hline $\mathrm{Co}-\mathrm{O} 10(\times 2)$ & $2.0618(15)$ & $2.072(2)$ & $\mathrm{Cu} 2-\mathrm{O} 2$ & $1.9195(14)$ & $1.9212(18)$ \\
$-\mathrm{O} 9(\times 2)$ & $2.0620(15)$ & $2.076(2)$ & $-\mathrm{O} 2^{\prime}$ & $1.9351(14)$ & $1.9357(18)$ \\
$-\mathrm{O} 8(\times 2)$ & $2.0919(15)$ & $2.098(2)$ & $-\mathrm{O} 3$ & $2.0192(15)$ & $2.0221(19)$ \\
$\langle\mathrm{Co}-\mathrm{O}\rangle$ & 2.072 & 2.082 & $-\mathrm{O} 4$ & $2.0223(14)$ & $2.0289(19)$ \\
& & & $-\mathrm{O} 1$ & $2.3333(15)$ & $2.3380(18)$ \\
$\mathrm{Cu} 1-\mathrm{O} 4$ & $1.9845(14)$ & $1.9866(18)$ & $-\mathrm{O} 1^{\prime}$ & $2.3793(15)$ & $2.3884(18)$ \\
$-\mathrm{O} 4{ }^{\prime}$ & $1.9909(14)$ & $1.9980(18)$ & $\langle\mathrm{Cu} 2-\mathrm{O}\rangle$ & 2.101 & 2.106 \\
$-\mathrm{O} 3$ & $2.0077(14)$ & $2.0146(18)$ & & & \\
$-\mathrm{O} 3^{\prime}$ & $2.0273(15)$ & $2.0355(18)$ & $\mathrm{S}-\mathrm{O} 7$ & $1.4731(15)$ & $1.468(2)$ \\
$-\mathrm{O} 2$ & $2.2905(16)$ & $2.289(2)$ & $-\mathrm{O} 5$ & $1.4766(16)$ & $1.468(2)$ \\
$-\mathrm{O} 1$ & $2.3449(16)$ & $2.346(2)$ & $-\mathrm{O} 6$ & $1.4801(16)$ & $1.474(2)$ \\
$\langle\mathrm{Cu} 1-\mathrm{O}\rangle$ & 2.108 & 2.112 & $-\mathrm{O} 1$ & $1.4810(15)$ & $1.4851(18)$ \\
& & & $\langle\mathrm{S}-\mathrm{O}\rangle$ & 1.478 & 1.474 \\
\hline
\end{tabular}

Table 5. Hydrogen bonding in gobelinite from Cap Garonne.

\begin{tabular}{lrrrrr}
\hline D-H & $d$ (D-H) & $d$ (H..A $)$ & $<$ DHA & $d$ (D..A $)$ & A \\
\hline O2-H2 & 0.899 & 2.105 & 143.32 & 2.876 & O7 \\
O4-H4 & 0.800 & 2.385 & 138.53 & 3.031 & O5 \\
O8-H81 & 0.884 & 1.846 & 168.6 & 2.718 & O5 \\
O8-H82 & 0.899 & 1.883 & 167.91 & 2.769 & O6 \\
O9-H91 & 0.896 & 2.175 & 136.91 & 2.895 & O6 \\
O9-H91 & 0.896 & 2.6 & 148.48 & 3.396 & O10 \\
O9-H92 & 0.893 & 1.809 & 174.26 & 2.699 & O7 \\
O10-H101 & 0.906 & 1.827 & 175.17 & 2.731 & O6 \\
O10-H101 & 0.906 & 2.649 & 121.24 & 3.213 & O7 \\
O10-H102 & 0.871 & 1.956 & 168.87 & 2.816 & O5 \\
\hline
\end{tabular}

D: donor; A: acceptor; $d$ : distance.

Two-sided tetrahedral decoration of brucite-like, $M \mathrm{O}_{6}$ based $(M=\mathrm{Cu}, \mathrm{Zn})$ sheets occurs in the crystal structures of schulenbergite, devilline, campigliaite, niedermayrite, christelite and serpierite (Hawthorne et al., 2000; Hawthorne and Schindler, 2000), all of which contain interlayer cations except schulenbergite. However, gobelinite has a different linkage of $\mathrm{H}$ bonds, and the interlayer cation forms an unconnected polyhedron which is held in the structure by hydrogen bonds of medium-weak to weak strength only (Fig. 3). These hydrogen bonds have donor-acceptor distances ranging from 2.706 to $3.399 \AA$ (EZ; $298 \mathrm{~K}$ values) and 2.716 to $3.031 \AA$ (CG; $100 \mathrm{~K}$ values; Table 5). The three shortest hydrogen

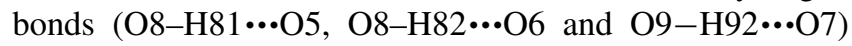
strengthen the structural network in the (010) plane. It is noteworthy that there is no difference between the hydrogenbonding network in gobelinite and that of ktenasite sensu stricto (Mellini et al., 1981). The positions of the hydrogen bonds are within experimental error between the two minerals, and there are no new linkages found in the structure of gobelinite.

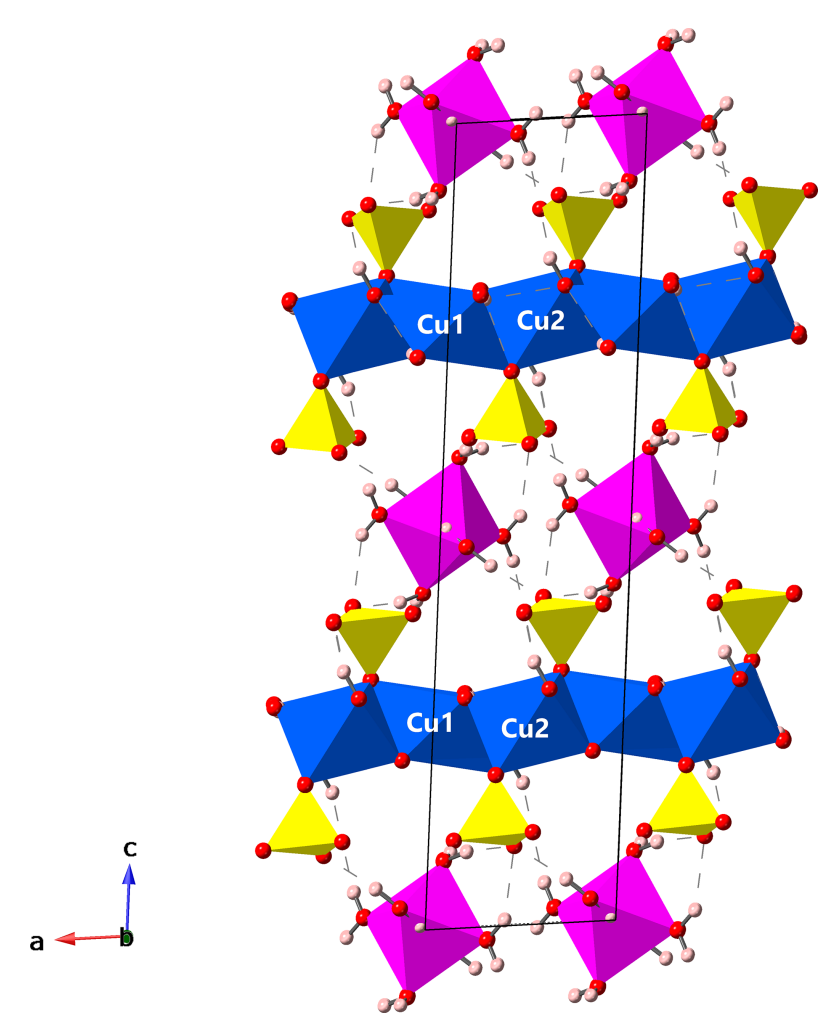

Figure 3. Crystal structure of gobelinite from Cap Garonne in a view along [010], parallel to the brucite-like sheets. Jahn-Tellerdistorted $\mathrm{CuO}_{6}$ octahedra (blue), regular $\mathrm{CoO}_{6}$ octahedra (magenta), $\mathrm{SO}_{4}$ tetrahedra (yellow), $\mathrm{O}$ atoms (red) and $\mathrm{H}$ atoms (pale pink). The unit cell is outlined. Hydrogen bonds are shown as dashed lines. Drawing done with CrystalMaker (Palmer, 2009).

\section{Relationship to other minerals}

Gobelinite is the Co analogue of ktenasite, ideally $\mathrm{ZnCu}_{4}\left(\mathrm{SO}_{4}\right)_{2}(\mathrm{OH})_{6} \cdot 6 \mathrm{H}_{2} \mathrm{O}$, with $\mathrm{Co}$ replacing $\mathrm{Zn}$ in the interlayer octahedrally coordinated $M 1$ site. It also 
represents the $\mathrm{Co}$ analogue of the recently approved fehrite, $\mathrm{MgCu}_{4}\left(\mathrm{SO}_{4}\right)_{2}(\mathrm{OH})_{6} \cdot 6 \mathrm{H}_{2} \mathrm{O}$ (Schlüter et al., 2020). Gobelinite from the Eisenzecher Zug was originally reported as a Zn-free, but Co- and Ni-bearing "ktenasite", "ktenasite(Co,Ni)" or "ktenasite-Co" by Henrich (1998, 2008a, b). Sarp et al. (1990) reported a "cobalt-nickel-kténasite" from Cap Garonne, for which the bulk chemical formula $\left(\mathrm{Cu}_{3.53} \mathrm{Co}_{0.80} \mathrm{Ni}_{0.61} \mathrm{Zn}_{0.23}\right)_{\Sigma 5.17}\left(\mathrm{SO}_{4}\right)_{1.98}(\mathrm{OH})_{6.38} \cdot 5.7 \mathrm{H}_{2} \mathrm{O}$ was given, calculated on the basis of $20 \mathrm{O}$ atoms. Considering the $\mathrm{Co}$ dominance among the non- $\mathrm{Cu}$ metal atoms, this phase very probably is a Ni-rich gobelinite, although the exact distribution of $\mathrm{Ni}$ on the three $M$ sites in the crystal structure was not determined. Nicholas Meisser (personal communication, 1999, to Uwe Kolitsch) analysed a ktenasite sample from the La Creusa uranium prospect, Valais, Switzerland, which showed the presence of $\mathrm{Cu}, \mathrm{Zn}$ and $\mathrm{Co}$ in the approximate ratio of $5: 1: 1$; i.e. this sample is a $1: 1$ intermediate solid-solution member in the series between ktenasite and gobelinite. A ktenasite with $\mathrm{Zn}$ dominant on the $\mathrm{Zn}$ site, but containing additional minor Co and traces of $\mathrm{Pb}$ and $\mathrm{Ni}$, was described from a Japanese locality by Ohnishi et al. (2002). These reports suggest that a complete solid-solution series exists between ktenasite and gobelinite. A possible $\mathrm{Ni}$ analogue (Co-bearing) of ktenasite from Cap Garonne (pillar 80) is currently under study by the authors.

A "Cu-dominant analogue" from Cap Garonne is also reported by Favreau and Galea-Clolus (2014); however, no chemical formula was given. A very Zn-rich ktenasite sample was reported by Livingstone (1991) from two mines in Cumbria, Great Britain. Based on quantitative chemical analyses, the formula $\mathrm{Zn}_{2}\left(\mathrm{Zn}_{4}\right)_{4}\left(\mathrm{Zn}_{3.48} \mathrm{Cu}_{0.52}\right)_{\Sigma 4.00}$ was given, "clearly indicating $\mathrm{Zn}$ dominance in the two $\mathrm{Cu}$ sites for ktenasite". However, neither unit-cell parameters nor crystal structure were determined, and no direct proof for this assumption is available yet; samples from many localities, and having strongly variable $\mathrm{Cu}: \mathrm{Zn}$ ratios, studied by us and colleagues have never had such a Zn-rich composition, and we consider this report doubtful.

Data availability. Crystallographic data for gobelinite are available in the Supplement.

Supplement. The supplement related to this article is available online at: https://doi.org/10.5194/ejm-32-637-2020-supplement.

Author contributions. VGC and JMH found the mineral and provided valuable information, as did GF. SJM, UK and WDB analysed the material (structure determinations were done by SJM and UK, EPMA by WDB, and SEM-EDS by UK), interpreted the results and wrote the paper, with help from GF.
Competing interests. The authors declare that they have no conflict of interest.

Acknowledgements. This research was undertaken in part using the MX2 beamline at the Australian Synchrotron, part of ANSTO, and made use of the Australian Cancer Research Foundation (ACRF) detector. Günter Blass is thanked for preliminary studies of gobelinite (EZ) samples. Graham Hutchinson is thanked for help with the electron-microprobe analyses. The article benefited from constructive reviews by Jochen Schlüter and Taras Panikorovskii. We thank Pierre Clolus for providing the colour photo.

Financial support. Part of the work of Uwe Kolitsch was undertaken while he was financially supported by the Deutsche Forschungsgemeinschaft (DFG) and the Austrian Fonds zur Förderung der wissenschaftlichen Forschung (FWF).

Review statement. This paper was edited by Sergey Krivovichev and reviewed by Taras Panikorovskii and one anonymous referee.

\section{References}

Ashliman, D. L.: Fairy Lore: A Handbook, Greenwood Press, Westport, CT, USA, 2006.

Bruker: SADABS and XPREP, Bruker AXS Inc., Madison, WI, USA, 2001.

Favreau, G.: FACES, available at: http://un2sg4.unige.ch/athena/ html/sc_prg.html (last access: 4 November 2020), 2005

Favreau, G. and Galea-Clolus, V.: Cap Garonne, Association Française de Microminéralogie, Carry-le-Rouet, France, 2014.

Hawthorne, F. C. and Schindler, M.: Topological enumeration of decorated $\left[\mathrm{Cu}^{2+} \varphi_{2}\right]_{N}$ sheets in hydroxy-hydrated copper-oxysalt minerals, Can. Mineral., 38, 751-761, https://doi.org/10.2113/gscanmin.38.3.751, 2000.

Hawthorne, F. C., Krivovichev, S. V., and Burns, P. C.: The crystal chemistry of sulfate minerals, Rev. Mineral. Geochem., 40, 1112, https://doi.org/10.2138/rmg.2000.40.1, 2000.

Henrich, J. M.: Die Königin der Eisensteingruben. Die Grube Eisenzecher Zug bei Eiserfeld im Siegerland - ein Fundort begehrter Mineralien, Mineralien-Welt, 9, 16-35, 1998.

Henrich, M.: Neues von der Grube Eisenzecher Zug, Eiserfeld, Mineralien-Welt, 19, 16-25, 2008a.

Henrich, M.: Sekundäre Kupfermineralien von der Grube Eisenzecher Zug im Siegerland, Lapis, 33, 45, $2008 \mathrm{~b}$.

Kabsch, W.: XDS, Acta Crystallogr., D66, 125-132, https://doi.org/10.1107/S0907444909047337, 2010.

Kokkoros, P.: Ktenasit, ein Zink-Kupfersulfat aus Lavrion (Griechenland), Tschermaks Mineral. Petrogr. Mitt., 1, 342-346, https://doi.org/10.1007/BF01145389, 1950.

Livingstone, A.: The zinc analogue of ktenasite from Smallcleugh and Brownley Hill mines, Nenthead, Cumbria, J. Russel Soc., 4, 13-15, 1991.

Mandarino, J. A.: The Gladstone-Dale compatibility of minerals and its use in selecting mineral species 
for further study, Can. Mineral., 45, 1307-1324, https://doi.org/10.2113/gscanmin.45.5.1307, 2007.

Mellini, M. and Merlino, S.: Ktenasite, another mineral with $\left.{ }_{\infty}^{2}\left[(\mathrm{Cu}, \mathrm{Zn})_{2}(\mathrm{OH})_{3} \mathrm{O}\right)\right]^{-}$octahedral sheets, Z. Kristallogr., 147, 129-140, https://doi.org/10.1524/zkri.1978.147.14.129, 1978.

Mellini, M., Orlandi, P., and Boscardin, M.: Chemical and crystallographic data for ktenasite, Rend. Soc. Ital. Mineral. Petrol., 37, 409-414, 1981.

Mills, S. J., Missen, O. P., and Favreau, G.: The crystal structure of Ni-rich gordaite-thérèsemagnanite from Cap Garonne, France, Mineral. Mag., 83, 459-463, https://doi.org/10.1180/mgm.2019.6, 2019.

Miyawaki, R., Hatert, F., Pasero, M., and Mills, S. J.: New minerals and nomenclature modifications approved in 2019, Mineral. Mag., 83, 887-893, https://doi.org/10.1180/mgm.2019.73, 2019.

Ohnishi, M., Kobayashi, S., and Kusachi, I.: Ktenasite from the Hirao mine at Minoo, Osaka, Japan, J. Mineral. Petrol. Sci., 97, 185-189, https://doi.org/10.2465/jmps.97.185, 2002.

Otwinowski, Z., Borek, D., Majewski, W., and Minor, W.: Multiparametric scaling of diffraction intensities, Acta Crystallogr. A, 59, 228-234, https://doi.org/10.1107/S0108767303005488, 2003.

Olsen, E. and Lewis, C. F.: Ktenasite from Creede, Colorado, Am. Mineral., 64, 446-448, 1979.

Palmer, D.: CrystalMaker, CrystalMaker Software Ltd, Yarnton, England, 2009.

Pfeifer, W.: Etymologisches Wörterbuch des Deutschen, 7th edn., Deutscher Taschenbuch Verlag, Munich, 2004.
Raade, G.: New data on ktenasite, Mineral. Mag., 41, 65-71, https://doi.org/10.1180/minmag.1977.041.317.10, 1977.

Sarp, H., Perroud, P., and Camerola, M.: Cobalt nickel-kténasite de la mine de Cap Garonne (Var), France, nouvelle variété de kténasite, Schweiz. Mineralog. Petrogr. Mitt., 70, 333-335, 1990.

Schlüter, J., Malcherek, T., Mihailova, B., Rewitzer, C., Hochleitner, R., Müller, D., and Günther, A.: Fehrite, $\mathrm{MgCu}_{4}\left(\mathrm{SO}_{4}\right)_{2}(\mathrm{OH})_{6} \cdot 6 \mathrm{H}_{2} \mathrm{O}$, the magnesium analogue of ktenasite from the Casualidad mine near Baños de Alhamilla, Almeria, Spain, N. Jb. Miner. Abh. https://doi.org/10.1127/njma/2020/0218, 2020.

Shannon, R. D.: Revised effective ionic radii and systematic studies of interatomic distances in halides and chalcogenides, Acta Crystallogr., A32, 751-767, 1976.

Sheldrick, G. M.: A short history of SHELX, Acta Crystallogr., A64, 112-122, https://doi.org/10.1107/S0108767307043930, 2008.

Sheldrick, G. M.: Crystal structure refinement with SHELXL, Acta Crystallogr. C, 71, 3-8, https://doi.org/10.1107/S2053229614024218, 2015a.

Sheldrick, G. M.: SHELXT - Integrated space-group and crystal-structure determination, Acta Crystallogr. A, 71, 3-8, https://doi.org/10.1107/S2053273314026370, 2015b.

Wildner, M.: On the geometry of $\mathrm{Co}(\mathrm{II}) \mathrm{O}_{6}$ polyhedra in inorganic compounds, Z. Kristallogr., 202, 51-70, https://doi.org/10.1524/zkri.1992.202.14.51, 1992. 